\title{
PENGARUH PENGGUNAAN LARUTAN ALKALI PADA KEKUATAN TARIK DAN UJI DEGRADASI KOMPOSIT POLIPROPILENA BEKAS BERPENGISI SERBUK SERABUT KELAPA
}

\author{
Fitriah Sari Nst, Harry Abrido S, Maulida \\ Departemen Teknik Kimia, Fakultas Teknik, Universitas Sumatera Utara, \\ Jl. Almamater Kampus USU Medan 20155, Indonesia \\ email : Fitriahsari@students.usu.ac.id
}

\begin{abstract}
Abstrak
Komposit merupakan gabungan dua bahan atau lebih yang berlainan untuk memperoleh bahan dengan sifat-sifat fisik dan mekanik yang lebih baik dibandingkan sifat setiap komponen pembentuknya. Salah satu jenis komposit yang banyak dihasilkan adalah komposit berpengisi serbuk alami. Penelitian ini menggunakan matriks polipropilena bekas yang berasal dari botol minuman cup bekas dan pengisi serbuk serabut kelapa yang telah diolah dengan Natrium Hidroksida (NaOH).Rasio perbandingan antara matriks dan pengisi adalah 85:15. Rasio ini merupakan nilai optimum yang diperoleh berdasarkan kekuatan uji tarik komposit dengan beberapa rasio yaitu 100:0 , 95:5, 90:10 dan 85:15. Tujuan penelitian ini adalah untuk mengetahui pengaruh penggunaan larutan alkali terhadap sifat komposit yang dihasilkan berupa kekuatan tarik, serta pengaruh uji degradasi terhadap bahan komposit polipropilen bekas berpengisi serabut kelapa. Variasi uji degradasi komposit adalah 10, 20 dan 30 hari dan perendaman serbuk selama 1 dan 2 hari. Metode yang digunakan dalam pembuatan komposit ini adalah metode ekstrusi. Matriks berupa polipropilena bekas dicampur dengan serbuk serabut kelapa yang telah direndam dengan $\mathrm{NaOH}$, kemudian dicampur di dalam sebuah wadah, kemudian dimasukkan ke dalam ekstruder dengan suhu operasi $175^{\circ} \mathrm{C}$, dicetak dengan menggunakan hot press pada suhu $175^{\circ} \mathrm{C}$, dan dipotong-potong sesuai pengujian. Hasil penelitian menunjukkan bahwa terjadi pengolahan optimum dengan $\mathrm{NaOH}$ selama 2 hari. Hasil uji degradasi menunjukkan perendaman selama 2 hari memiliki nilai kekuatan tarik yang lebih tinggi dibandingkan 1 hari yaitu sebesar 29,023 MPa pada 0 hari, 28,835 MPa pada 10 hari, 26,762 MPa pada 20 hari dan 25,361 MPa pada 30 hari.
\end{abstract}

Kata kunci: komposit, polipropilena bekas, serabut kelapa, $\mathrm{NaOH}$, uji degradasi, uji tarik

\begin{abstract}
Composite is a combination of two different materials to obtain a material with physical properties and mechanical properties are better than any of its constituent parts. One of the many types of produced composite is composite with powdered natural fiber. This study uses the former polypropylene matrix derived from former cup bottle cup and powdered coconut fiber as filler treated with Sodium Hydroxide (NaOH). The ratio of the matrix and the filler is 85:15. This ratio is the optimum value obtained by the composite tensile strength with some ratios are 100:0, 95:5, 90:10 and 85:15. The purpose of this study was to determine the effect of the use of an alkaline solution of the resulting composite properties such as tensile strength, as well as the effect of degradation test on composite material former polypropylene with powdered coconut fiber as filler. Variation of composite degradation test were 10, 20 and 30 days, and immersion powder for 1 and 2 days. The method used in the manufacture of composites is the method of extrusion. The matrix form of the former polypropylene mixed with coconut fiber powder that has been soaked with $\mathrm{NaOH}$, then mixed in a container, then put into the extruder operating temperature $1750 C$, printed using a hot press at a temperature of $1750 \mathrm{C}$, and cut into pieces appropriate testing. The results showed that the optimum processing occurs with $\mathrm{NaOH}$ for 2 days. The test results showed degradation soaking for 2 days has tensile strength values higher than 1 day is equal to 29,023 MPa at 0 day, 28,835 MPa at 10 days, 26,762 MPa at 20 days and 25,361 MPa at 30 days.
\end{abstract}

Keywords : composite, former polypropylene, coconut fiber, $\mathrm{NaOH}$, degradation test, tensile strength

\section{Pendahuluan}

Pada dekade terakhir ini perkembangan teknologi semakin pesat, terutama di bidang bahan teknik. Salah satu kemajuan di bidang bahan teknik adalah pemanfaatan bahan komposit untuk berbagai keperluan seperti alat transportasi baik transportasi darat, laut, dan udara.Komposit dengan berpenguat serat alam menjadi salah satu pilihan yang tepat. Serat alam 
lebih dipilih dibanding serat buatan, karena serat alam memiliki beberapa kelebihan diantaranya adalah kaku, murah, ringan, tidak beracun, tersedia dalam jumlah yang banyak dan ramah lingkungan [6][10].

Adapun salah satu jenis tanaman yang menghasilkan serat alam adalah kelapa dengan nama latin Cocos nucifera. Selama ini serabut kelapa hanya digunakan sebagai bahan dasar pembuatan keset, sikat, dan lain-lain[2]. Hal yang menjadi pertimbangan penggunaan serat ini adalah serat ini mudah diperoleh serta serat ini juga memiliki sifat yang kuat. Penelitian mengenai penggunaan serabut kelapa sebagai pengisi komposit termoplastik telah banyak dilakukan. Salah satu penelitian dilakukan oleh University of Delft, dimana komposit polipropilen berpengisi serabut kelapa menghasilkan flexural strength 29-49 MPa dan flexural stiffness 2,91-2,99 GPa [4].

Jenis termoplastik yang digunakan dalam penelitian ini adalah polipropilen (PP) bekas yang berasal dari botol minuman cup bekas. Polipropilen (PP) adalah sebuah polimer termoplastik yang dibuat oleh industri kimia dan digunakan dalam berbagai aplikasi.

Penggunaan larutan alkali sebagai langkah perlakuan terhadap serat telah dilakukan. Salah satunya dilakukan oleh Kuncoro dimana poliester berpengisi serat rami diperlakukan dengan larutan alkali yaitu larutan natrium hidrosida $(\mathrm{NaOH})$. Komposit yang dihasilkan memiliki kekuatan tarik $190 \mathrm{MPa}$ dan modulus elastisitas 45,795 GPa [6]. Penelitian yang dilakukan Rohatgi menyatakan perendaman serabut kelapa dalam larutan 5\% $\mathrm{NaOH}$ selama 72 jam memberikan kekuatan tarik terbaik [15]. Berbeda dengan Mohanty menyatakan perendaman dalam larutan $2 \% \mathrm{NaOH}$ selama 1 jam memberikan kekuatan tarik optimum [12].

Plastik inovatif sebagai bahan bangunan pengganti kayu. Di lain pihak, seiring dengan perkembangan teknologi, kebutuhan akan plastik terus meningkat. Sebagai konsekuensinya, peningkatan limbah plastikpun tidak terelakkan. Limbah plastik merupakan bahan yang tidak dapat terdekomposisi oleh mikroorganisme pengurai, sehingga penumpukkannya di alam dikhawatirkan akan menimbulkan masalah lingkungan. Oleh karena itu penelitian ini juga bermanfaat untuk mendaur ulang limbah plastik yaitu polipropilen bekas dari aqua cup untuk mengurangi penumpukan limbah plastik di alam. Pengujian degradasi komposit termoplastik dalam penelitian ini juga dilakukan didasarkan atas penelitian yang telah dilakukan untuk meneliti degradasi komposit [14].

\section{Teori}

Komposit adalah bahan padat yang dihasilkan melalui kombinasi dari dua atau lebih bahan yang berlainan dengan sifat-sifat yang lebih baik dan tidak dapat diperoleh dari setiap komponen penyusunnya. Komposit sudah digunakan oleh manusia sejak awal abad ke-12. Dewasa ini, pemakaian bahan komposit semakin banyak digunakan seperti dalam bidang penerbangan, konstruksi bangunan, automobil, peralatan olahraga, perabot dan sebagainya [9].

Komposit mempunyai banyak kelebihan dan keistimewaan dari segi sifat mekanis, fisik, termal, dan kimianya, yaitu:

a) Sifat kekuatan, kekakuan dan keliatannya yang cukup baik

b) Kestabilan dimensi dan ketahanan termal yang tinggi.

c) Peningkatan modulus spesifik (modulus / massa jenis) dan kekuatan spesifik (kekuatan / massa jenis) menyebabkan berat jenis komposit semakin berkurang.

d) Peningkatan ketahanan terhadap bahan kimia.

e) Biaya produksi dapat dikurangi karena bahan dasar yang digunakan berkurang.

Namun perlu diketahui bahwa semua sifat diatas tidak dapat diperoleh secara bersamaan. Misalnya, peningkatan sifat kekakuan dan kekuatan umumnya mengurangi sifat keliatan bahan komposit tersebut. Jadi pencapaian kekuatan optimum komposit yang dihasilkan disesuaikan dengan penggunaan komposit tersebut.

Sodium Hydroxide atau Natrium Hidroksida adalah sejenis basa logam kaustik. Zat ini digunakan di berbagai macam bidang industri, kebanyakan digunakan sebagai basa dalam proses produksi bubur kayu dan kertas, tekstil, air minum, sabun dan deterjen. Kegunaan $\mathrm{NaOH}$ ini adalah untuk menghilangkan lignin, silika hemiselulosa, dan empulur dari serat agar memiliki impregnasi lebih baik antara serat dan matriks dan meningkatkan kekasaran permukaan serat agar dapat terjadi interaksi yang lebih baik yang menjadi tujuan utama pengolahan secara kimia [15].

polipropena (PP) merupakan hidrokarbon yang termasuk ke dalam polimer termoplastik yang dapat diolah pada suhu tinggi. Polipropilen berasal dari monomer propilen yang diperoleh dari pemurnian minyak bumi. 
Struktur molekul propilen dapat dilihat pada gambar 1 berikut.<smiles>C=CC</smiles>

\section{Gambar 1. Struktur Molekul Propilen}

Adapun karakteristik dari PP dapat dilihat pada Tabel 2.1.

Tabel 2.1 Karakteristik Polipropilen [17]

\begin{tabular}{|l|l|l|}
\hline Sifat-sifat & Nilai & Satuan \\
\hline Densitas & 0,9 & $\mathrm{~g} / \mathrm{cm}^{3}$ \\
\hline Tensile Strength & 360 & $\mathrm{~kg} / \mathrm{cm}^{2}$ \\
\hline Pemanjangan/Elongation & 8 & $\%$ \\
\hline $\begin{array}{l}\text { Daya serap air setelah } 24 \\
\text { jam }\end{array}$ & 0,02 & $\%$ \\
\hline $\begin{array}{l}\text { Modulus kelenturan } \\
\text { (Flexural modulus) }\end{array}$ & 17.000 & $\mathrm{~kg} / \mathrm{cm}^{2}$ \\
\hline Titik leleh & 176 & ${ }^{0} \mathrm{C}$ \\
\hline
\end{tabular}

Serabut kelapa berada diantara tempurung kelapa dan kulit kelapa. Setiap sel serat berbentuk panjang dan berongga dengan dinding tipis yang terbuat dari selulosa. Dinding ini lemah saat masih muda namun semakin lama semakin mengeras dan menguning dimana terbentuk lapisan lignin pada dindingnya. Tiap sel memiliki panjang $1 \mathrm{~mm}(0,04 \mathrm{in})$ dan berdiameter $10-20 \mu \mathrm{m}(0,0004-$ 0,0008 in). Seratnya memiliki panjang $10-20 \mathrm{~cm}$ (4-12 in). Terdapat 2 jenis dari serabut kelapa. Jenis pertama adalah berwarna coklat yang diperoleh dari kelapa yang sudah tua. Serat ini tipis, dan kuat sehingga digunakan untuk sikat dan keset kaki [3].

Tabel 2.2 Sifat-sifat Fisika Serabut Kelapa [4]

\begin{tabular}{|l|l|l|}
\hline Sifat-sifat & Nilai & Satuan \\
\hline Densitas & 1,25 & $\mathrm{~g} / \mathrm{cm}^{3}$ \\
\hline Tensile Strength & 220 & $\mathrm{MPa}$ \\
\hline $\begin{array}{l}\text { Elongation } \\
\text { modulus }\end{array}$ & 6 & $\mathrm{GPa}$ \\
\hline $\begin{array}{l}\text { Elongation at } \\
\text { failure }\end{array}$ & $15-25$ & $\%$ \\
\hline
\end{tabular}

Tabel 2.3 Komposisi Kimia Serabut Kelapa [11]

\begin{tabular}{|l|l|}
\hline Komposisi & Nilai (\%) \\
\hline Selulosa & $32-43$ \\
\hline Hemiselulosa & $0,15-0,25$ \\
\hline Lignin & $40-45$ \\
\hline Pektin & $3-4$ \\
\hline Kelembaban & 8 \\
\hline
\end{tabular}

Adapun Tabel 2.2 dan Tabel 2.3 menunjukkan sifat-sifat fisika dan kimia dari serabut kelapa.

Komposit memiliki banyak jenis uji, tetapi yang dibahas dalam penelitian ini adalah sebagai berikut:

1.Sifat Kekuatan Tarik (Tensile Strength)

Sifat mekanis biasanya dipelajari dengan mengamati sifat kekuatan tarik $\left(\tau_{\mathrm{t}}\right)$ menggunakan alat tensometer. Secara praktis kekuatan tarik diartikan sebagai besarnya beban maksimum $\left(\mathrm{F}_{\text {maks }}\right)$ yang dibutuhkan untuk memutuskan spesimen bahan dibagi dengan luas penampang bahan. Karena selama dibawah pengaruh tegangan spesimen mengalami perubahan bentuk (deformasi), maka defenisi kekuatan tarik dinyatakan dengan luas penampang semula $\left(\mathrm{A}_{\mathrm{o}}\right)$.

$$
\tau_{\mathrm{t}}=\mathbf{F}_{\text {maks }} / \mathbf{A}_{\mathbf{o}}
$$

Dimana $\tau_{\mathrm{t}}$ : Kekuatan tarik

$$
\begin{aligned}
& \mathrm{F}_{\text {maks }} \text { : Beban maksimum } \\
& \mathrm{A}_{\mathrm{o}} \text { : Luas penampang mula-mula } \\
& \mathrm{d} \text { : Lebar }
\end{aligned}
$$

\section{Uji degradasi}

Degradasi dari polimer melalui suatu tahap, dimana pertama polimer diubah menjadi monomer, lalu monomer tersebut menjadi mineral. Kebanyakan polimer terlalu besar untuk melalui membran sel, jadi polimer tersebut terlebih dahulu di depolimerisasi menjadi monomer-monomer sebelum diserap dan dibiodegradasi oleh mikroba. Pemecahan awal dari sebuah polimer dapat diperoleh dari cara fisik, kimia dan biologi.

Pemecahan secara fisik berupa pemanasan/pendinginan, pembekuan/pencairan, pembasahan/pengeringan, dapat menghasilkan kerusakan mekanik berupa keretakan. Pertumbuhan dari jamur juga dapat membuat pembengkakkan dan letusan, dikarenakan jamur menembus permukaan padatan polimer. Hal ini memperburuk keadaan polimer dan membuat permukaan baru yang bereaksi dengan senyawa kimia dan biokimia, yang merupakan kondisi kritis pada degradasi polimer padatan [5].

Polipropilena dapat mengalami degradasi rantai saat terkena radiasi ultraungu dari sinar matahari. Jadi untuk penggunaan propilena di luar ruangan, bahan aditif yang menyerap ultraungu harus digunakan. Jelaga (celak) juga menyediakan perlindungan dari serangan UV. Polimer bisa dioksidasi pada suhu yang tinggi, merupakan permasalahan yang umum dalam operasi pencetakan. Antioksidan normalnya ditambahkan untuk mencegah degradasi atau oksidasi polimer. 


\section{Hasil}

1. Sifat Kekuatan Tarik, Pemanjangan Saat Putus, Modulus Young Komposit dengan Pengolahan $\mathrm{NaOH}$ pada Degradasi 10 hari

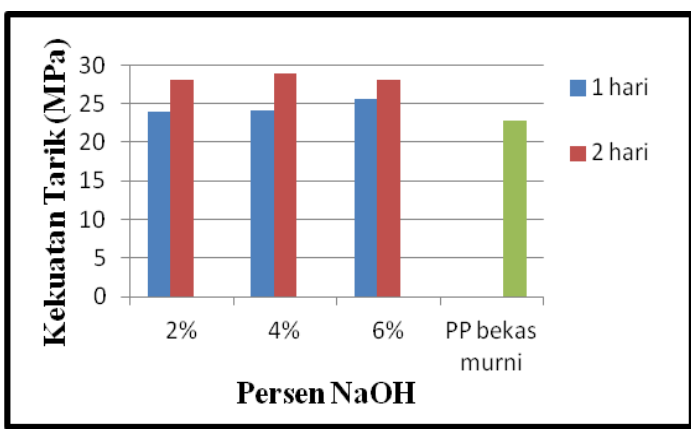

Gambar 2. Sifat Kekuatan Tarik Komposit pada Degradasi 10 hari

Dari gambar 2 di atas dapat dilihat bahwa kekuatan tarik komposit paling besar adalah pada pengolahan $4 \% \mathrm{NaOH}$ selama 2 hari. Kekuatan tarik terbaik pada pengolahan $\mathrm{NaOH}$ selama 1 hari adalah dengan pengolahan $\mathrm{NaOH} 6 \%$ yaitu sebesar 25,668 $\mathrm{MPa}$, sedangkan kekuatan tarik terbaik untuk pengolahan $\mathrm{NaOH}$ selama 2 hari adalah 2 . dengan pengolahan $\mathrm{NaOH} 4 \%$ yaitu sebesar 28,835 MPa. Kekuatan tarik PP bekas murni sebesar 22,747 MPa.

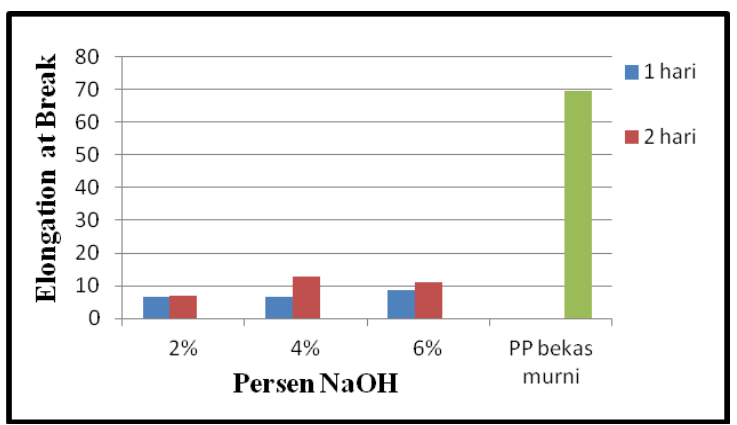

Gambar 3. Pemanjangan saat Putus Komposit pada Degradasi 10 hari

Dari gambar 3 di atas dapat dilihat bahwa pemanjangan saat putus komposit paling besar adalah pada pengolahan $4 \% \mathrm{NaOH}$ selama 2 hari. Pemanjangan saat putus terbaik pada pengolahan $\mathrm{NaOH}$ selama 1 hari adalah dengan pengolahan $\mathrm{NaOH} 6 \%$ yaitu sebesar 8,59, sedangkan pemanjangan saat putus terbaik untuk pengolahan $\mathrm{NaOH}$ selama 2 hari adalah dengan pengolahan $\mathrm{NaOH} 4 \%$ yaitu sebesar 12,86 . Pemanjangan saat putus PP bekas murni sebesar 69,34.

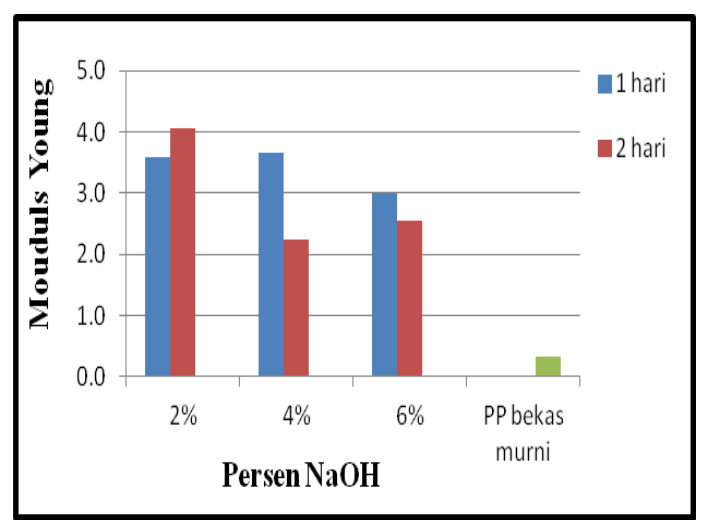

\section{Gambar 4. Modulus Young Komposit pada} Degradasi 10 hari

Dari gambar 4 di atas dapat dilihat bahwa modulus young komposit paling besar adalah pada pengolahan $2 \% \mathrm{NaOH}$ selama 2 hari. Modulus young terbesar pada pengolahan $\mathrm{NaOH}$ selama 1 hari adalah dengan pengolahan $\mathrm{NaOH} 4 \%$ yaitu sebesar 3,649, sedangkan modulus young terbesar untuk pengolahan $\mathrm{NaOH}$ selama 2 hari adalah dengan pengolahan $\mathrm{NaOH} 2 \%$ yaitu sebesar 4,052. Modulus Young PP bekas murni sebesar 0,328.

Sifat Kekuatan Tarik, Pemanjangan Saat Putus, Modulus Young Komposit dengan Pengolahan $\mathrm{NaOH}$ pada Degradasi 20 hari

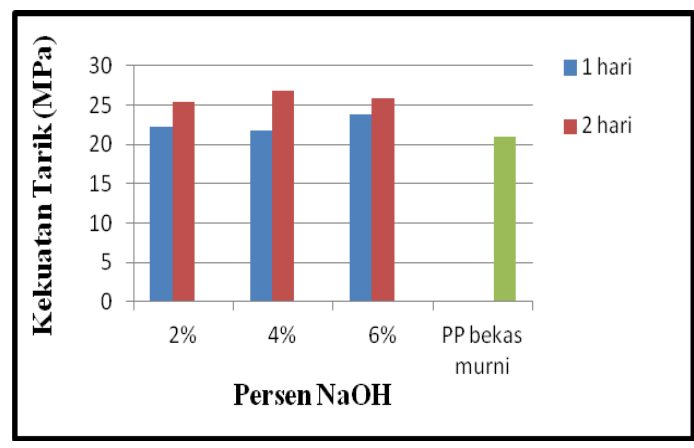

Gambar 5. Sifat Kekuatan Tarik Komposit pada Degradasi 20 hari

Dari gambar 5 di atas dapat dilihat bahwa kekuatan tarik komposit paling besar adalah pada pengolahan 4\% $\mathrm{NaOH}$ selama 2 hari. Kekuatan tarik terbaik pada pengolahan $\mathrm{NaOH}$ selama 1 hari adalah dengan pengolahan $\mathrm{NaOH} 6 \%$ yaitu sebesar 23,784 $\mathrm{MPa}$, sedangkan kekuatan tarik terbaik untuk pengolahan $\mathrm{NaOH}$ selama 2 hari adalah dengan pengolahan $\mathrm{NaOH} 4 \%$ yaitu sebesar 26,762 $\mathrm{MPa}$. Kekuatan tarik PP bekas murni sebesar 21,032 MPa. 


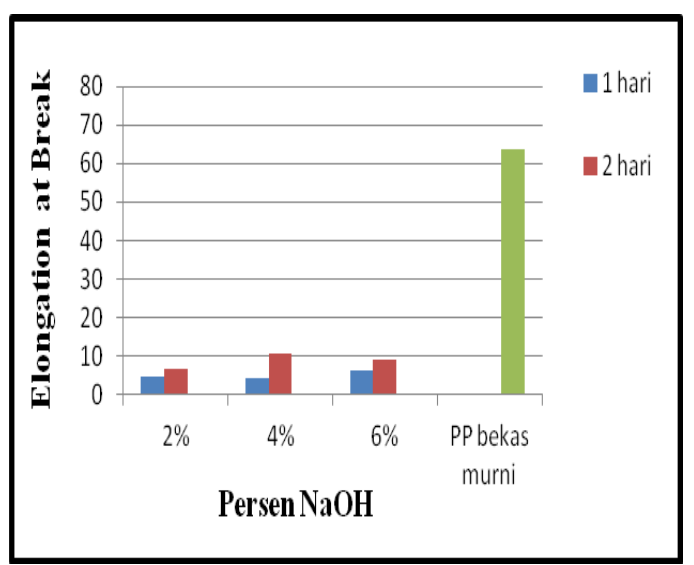

Gambar 6. Pemanjangan saat Putus Komposit pada Degradasi 20 hari

Dari gambar 6 di atas dapat dilihat bahwa pemanjangan saat putus komposit paling besar adalah pada pengolahan $4 \% \mathrm{NaOH}$ selama 2 hari. Pemanjangan saat putus terbaik pada pengolahan $\mathrm{NaOH}$ selama 1 hari adalah dengan pengolahan $\mathrm{NaOH} 6 \%$ yaitu sebesar 6,22, sedangkan pemanjangan saat putus terbaik untuk pengolahan $\mathrm{NaOH}$ selama 2 hari adalah dengan pengolahan $\mathrm{NaOH} \mathrm{4 \%} \mathrm{yaitu} \mathrm{sebesar} \mathrm{10,68.} \mathrm{Pemanjangan} \mathrm{saat}$ putus PP bekas murni sebesar 63,49.

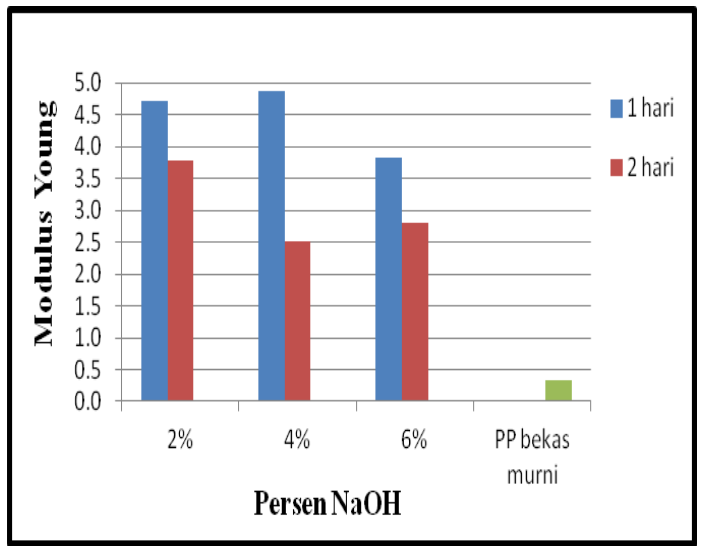

Gambar 7. Modulus Young Komposit pada Degradasi 20 hari

Dari gambar 7 di atas dapat dilihat bahwa modulus young komposit paling besar adalah pada pengolahan $4 \% \mathrm{NaOH}$ selama 1 hari. Modulus young terbesar pada pengolahan $\mathrm{NaOH}$ selama 1 hari adalah dengan pengolahan $\mathrm{NaOH} 4 \%$ yaitu sebesar 4,863, sedangkan modulus young terbesar untuk pengolahan $\mathrm{NaOH}$ selama 2 hari adalah dengan pengolahan $\mathrm{NaOH} 2 \%$ yaitu sebesar 3,786. Modulus Young PP bekas murni sebesar 0,331.
3. Sifat Kekuatan Tarik, Pemanjangan Saat Putus, Modulus Young Komposit dengan Pengolahan $\mathrm{NaOH}$ pada Degradasi 30 hari

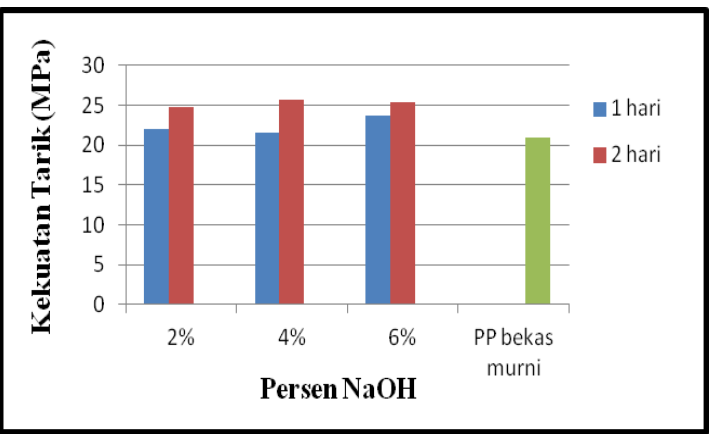

\section{Gambar 8. Sifat Kekuatan Tarik Komposit pada Degradasi 30 hari}

Dari gambar 8 di atas dapat dilihat bahwa kekuatan tarik komposit paling besar adalah pada pengolahan $4 \% \mathrm{NaOH}$ selama 2 hari. Kekuatan tarik terbaik pada pengolahan $\mathrm{NaOH}$ selama 1 hari adalah dengan pengolahan $\mathrm{NaOH} 6 \%$ yaitu sebesar 23,633 MPa, sedangkan kekuatan tarik terbaik untuk pengolahan $\mathrm{NaOH}$ selama 2 hari adalah dengan pengolahan $\mathrm{NaOH} 4 \%$ yaitu sebesar 25,631 MPa. Kekuatan tarik PP bekas murni sebesar 20,995 MPa.

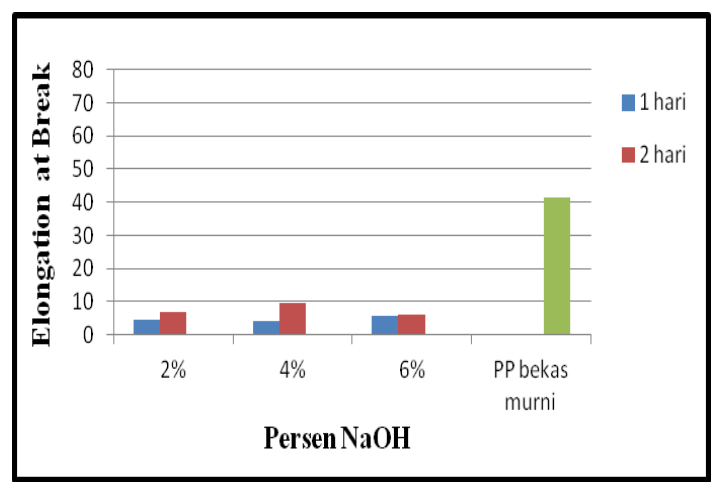

Gambar 9. Pemanjangan saat Putus Komposit pada Degradasi 30 hari

Dari gambar 9 di atas dapat dilihat bahwa pemanjangan saat putus komposit paling besar adalah pada pengolahan $4 \% \mathrm{NaOH}$ selama 2 hari. Pemanjangan saat putus terbaik pada pengolahan $\mathrm{NaOH}$ selama 1 hari adalah dengan pengolahan $\mathrm{NaOH} 6 \%$ yaitu sebesar 5,86, sedangkan pemanjangan saat putus terbaik untuk pengolahan $\mathrm{NaOH}$ selama 2 hari adalah dengan pengolahan $\mathrm{NaOH} 4 \%$ yaitu sebesar 9,48. Pemanjangan saat putus PP bekas murni sebesar 41,28. 


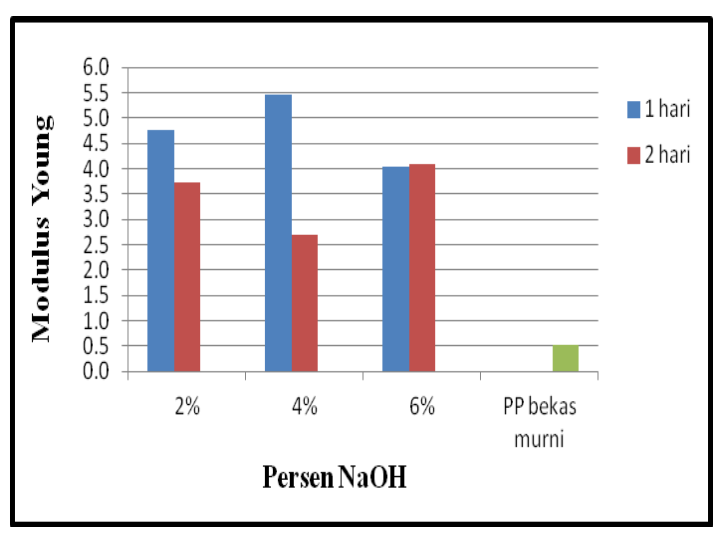

Gambar 10. Modulus Young Komposit pada Degradasi 30 hari

Dari gambar 10 di atas dapat dilihat bahwa modulus young komposit paling besar adalah pada pengolahan $4 \% \mathrm{NaOH}$ selama 1 hari. Modulus young terbesar pada pengolahan $\mathrm{NaOH}$ selama 1 hari adalah dengan pengolahan $\mathrm{NaOH} 4 \%$ yaitu sebesar 5,463, sedangkan modulus young terbesar untuk pengolahan $\mathrm{NaOH}$ selama 2 hari adalah dengan pengolahan $\mathrm{NaOH} 6 \%$ yaitu sebesar 4,091. Modulus Young PP bekas murni sebesar 0,508.

Dari hasil di atas dapat dilihat bahwa kekuatan tarik komposit paling besar adalah pada pengolahan $4 \% \mathrm{NaOH}$ selama 2 hari pada tiap uji degradasi. Kekuatan tarik pada pengolahan $4 \%$ $\mathrm{NaOH}$ selama 2 hari dengan degradasi 0 hari sebesar 29,023 MPa, pada 10 hari sebesar 28,835 $\mathrm{MPa}$, pada 20 hari sebesar 26,762 MPa, dan pada 30 hari sebesar 25,361 MPa.

Dari percobaan ini, peningkatan kekuatan tarik komposit polipropilena bekas berpengisi serbuk serabut kelapa disebabkan oleh berkurangnya kadar lignin di dalam serbuk serabut kelapa. Lignin berfungsi sebagai bahan pengkaku dan meningkatkan hidrofobitas pada molekul-molekul selulosa dalam dinding sel partikel organik. Kehadiran lignin yang bersifat nonpolar dalam serbuk serabut kelapa juga menambah kenonpolaran sehingga menyebabkan penurunan adhesi antar muka di antara pengisi dan matriks yang bersifat polar. Pengurangan kadar lignin disebabkan oleh pengolahan serbuk serabut kelapa dengan menggunakan $\mathrm{NaOH}$. Adapun pengaruh perendaman serbuk serabut kelapa oleh $\mathrm{NaOH}$ adalah untuk melepaskan lignin yang terdapat di dalam sebuk serabut kelapa, sehingga kadar lignin yang bersifat nonpolar di dalam serbuk serabut kelapa berkurang yang menyebabkan tingkat kenon-polaran serbuk serabut kelapa berkurang [15].

Pada uji degradasi diperoleh bahwa, terjadi penurunan kekuatan tarik selama proses degradasi dari 0 hari sampai 30 hari pada semua variasi pengolahan $\mathrm{NaOH}$ terhadap serbuk serabut kelapa. Seperti pada pengolahan $\mathrm{NaOH} 4 \%$ selama 2 hari mengalami penurunan kekuatan tarik dari 29,023 $\mathrm{MPa}, 28,835 \mathrm{MPa}, 26,762 \mathrm{MPa}, 25,361 \mathrm{MPa}$.

Dari percobaan uji degradasi, penurunan kekuatan tarik komposit selama 0 sampai 30 hari disebabkan oleh terpaparnya komposit oleh sinar UV yang berasal dari matahari dan perubahan suhu lingkungan dari siang ke malam. Penurunan sifat kekuatan tarik komposit disebabkan oleh gugus-gugus karbonil pada komposit menyerap sinar UV pada saat penjemuran dan penggantungan yang kemudian membentuk keadaan tereksitasi yang cukup berenergi untuk melakukan pembelahan/pemutusan ikatan. Selain itu, di udara juga terkandung banyak mikroorganisme yang didukung faktor lingkungan seperti suhu, uap air, sinar matahari, oksigen, dan kelembaban yang berasal dari pohon di dekatnya. Adapun plastik PP merupakan jenis termoplastik yang sensitif terhadap paparan radiasi dan panas matahari secara langsung, sehingga hal ini yang menyebabkan menurunnya kekuatan tarik pada komposit [16].

\section{Kesimpulan}

Adapun kesimpulan yang didapat dari penelitian ini adalah sebagai berikut:

1. Kekuatan tarik mengalami penurunan selama pengujian degradasi pada semua variasi $\mathrm{NaOH}$ terhadap serabut kelapa, seperti pada pengolahan $\mathrm{NaOH} 4 \%$ selama 2 hari yaitu 29,023 MPa pada 0 hari, 28,835 MPa pada 10 hari, 26,762 $\mathrm{MPa}$ pada 20 hari dan 25,361 MPa pada 30 hari.

2. Pengaruh larutan alkali pada serbuk serabut kelapa adalah mengurangi kadar lignin yang bersifat non polar pada serbuk serabut kelapa sehingga berkurang kenonpolarannya.

3. Waktu optimum untuk perendaman dengan $\mathrm{NaOH}$ adalah selama 2 hari.

\section{Daftar Pustaka}

[1] Anonim, Catalog of Chemicals, Titan PP Polymers (M) Sdn. Bhd. M, Kuala Lumpur, 1999.

[2] Anonim, 2010a, Coir, http//www. wikipedia.org, Diakses 4 April 2011.

[3] Anonim, 2010b, Polypropilene, http//www. wikipedia.org, Diakses 4 April 2011.

[4] Beukers A, dkk, Composite Applications using Coir Fibres in Sri Lanka, Delft University of Technology, Netherlands, 2004.

[5] Corning, Dow, Degradation of Polymers in Nature, Health Environment \& Regulatory Affairs (HERA), New York, 1998. 
[6] Diharjo, Kuncoro, Pengaruh Perlakuan Alkali terhadap Sifat Tarik Bahan Komposit Serat Rami-Polyester, Universitas Negeri Sebelas Maret, Solo, 2006.

[7] Halimatuddahliana, Pengenalan Teknologi Polimer, Departemen Teknik Kimia, Fakultas Teknik, Universitas Sumatera utara, Medan, 2006.

[8] Hariadi, Ihsan, 2000, Jurnal Fisika Bahan Komposit (1) dan (2), Milis Fisi Indonesia, www.Themailarchive.com, Diakses 4 April 2012.

[9] Ismail, H, Komposit Polimer Diperkuat Pengisi dan Gentian Pendek Semula Jadi, Kelantan, Universiti Sains Malaysia, 2010.

[10] Joseph K, dkk, Effect of Ageing On The Physical And Mechanical Properties of Short Sisal Fibre Reinforced Polyethylene Composites, Composites Science Technology, London, 1995.

[11] Luqman, Faruq, Coconut Coir as Natural Fibers For Polymer Composites, University Malaysia Perlis, Perlis, 2008.

[12] Mohanty, A. K, Coir-Polyester Composites: Effect On Fibre Surface Treatment On Mechanical Properties of Composite, New Delhi, 2000.

[13] Priyono, SKS, Komitmen Berbagai Pihak dalam Menanggulangi Illegal Logging, Kongres Kehutanan Indonesia III, Jakarta, 2001.

[14] Reynolds, Tom George, Accelerated Tests of Environmental Degradation in Composite Materials, Massachusetts Institute of Technology, Massachusetts , 1998.

[15] Rohatgi, P. K, Alkali Treatment For Coir Fibres For Coir-Polyester Composites, New Delhi, 1983.

[16] Stevens, M.P, Polimer Chemistry, Oxford University Press, London, 1989. 